\title{
TEACHING GEOGRAPHY 11-18: A CONCEPTUAL APPROACH
}

O livro Teaching Geography, de David Lambert e John Morgan², que uma vez mais publicam em parceria, mostra como a geografia contribui para o entendimento do mundo (ou partes dele). Este livro oferece uma nova abordagem para a compreensão do lugar da geografia na educação, mosrando o papel fundamental que os professores desempenham junto dos jovens.

Para os autores, os professores de geografia devem usar a sua disciplica para ajudar a envolver e estimular o interesse dos jovens para compreender o mundo e projetar e planejar o seu ensino.

Fazer isso é muito desafiador. Exige mais do que transmitir conhecimento, pois requer um engajamento intelectual com a disciplina, de modo que as suas perspectivas e "insights" possam ser aplicados em um contexto educacional. Não é sugerido que a escola e os professores devam ser obrigados a seguir cegamente os caprichos da disciplina acadêmica, mas que a geografia da escola esteja ciente do pensamento contemporâneo na disciplina.

Lambert e Morgan procuram enfatizar que esta é a fonte de excitação intelectual que nutre o relacionamento dos professores com os jovens. Os jovens são agentes de sua própria aprendizagem, e a expectativa da geografia na educação é que ela incentive a descoberta.

Este livro pode ser dividido em três partes. Na primeira parte, Conceitos, contextos $e$ histórias, oferece ao leitor:

a) Uma visão geral da geografia nas escolas. O que é realmente a geografia nas escolas? Qual é a sua narrativa global?

b) Um argumento para a continuidade de uma função geográfica nas escolas com base numa análise do mundo contemporâneo, explicando o papel crucial da educação de preparar os jovens para sociedade do conhecimento.

c) A necessidade de se refazer a relação dos professores com o ensino, interagindo a prática com a teoria, sem perca de eficácia.

1 Mestre em Fisica Ambiental da Universidade Federal de Mato Grosso-Brasil. E-mail: elisdener@hotmail.com

2 Lambert D, Morgan J (2010) Teaching Geography 11-18: a conceptual approach. Open University Press, Berkshire. 
Na segunda parte, Reconstruindo conceitos, oferece uma série de ensaios sobre uma seleção de grandes idéias na geografia. Os autores, cientes que essa abordagem de conceitos é bastante diferente daquela tomada por professores de geografia no passado, onde havia uma dependência da psicologia da aprendizagem, exacerbam que os conceitos servem antes de mais nada para contestação, e por isso são susceptíveis de possuir múltiplos significados que não podem ser reduzidos a uma única definição simples. Isto significa que as discussões dos conceitos apresentados nos capítulos não representam a "palavra final". Eles se destinam a provocar reflexão e alerta nos leitores de modo a desenvolverem suas próprias idéias. Essa é uma manobra deliberada de Lambert e Morgan, afim de contribuirem para uma leitura excitante.

Nos capítulos desta segunda parte, são retratadas uma seleção de idéias influentes pensadas e desenvolvidas em geografia, e suas implicações em seu ensino.

A escolha dos conceitos para serem discutidos não se pautaram nos sete conceitos-chave da National Curriculum que os autores acharam restritivos. E também queriam deliberadamente enfocar que estes sete conceitos não definem a geografia escolar. Inicialmente parecem ter ignorado certas idéias, como a "interação", "local" ou "mudança". No entanto, uma leitura atenta dos capítulos desta parte vai mostrar que estas idéias foram abordadas, tal como muitas outras.

$\mathrm{Na}$ terceira parte, desafios no Curriculum, apresenta um capítulo importante (capítulo 11), que explora os meios de cultura em que os jovens são muitas vezes imersos. Os conceitos discutidos são rotineiramente acessados através das mídias. Muitos dos lugares, espaços, temas e questões sobre a geografia são conhecidos através de filmes, notícias de televisão, documentários, jornais e, mais recentemente, sites e blogs. Embora seja óbvia a influência que os meios de comunicação têm sobre a geografia, há pouca discussão sobre a mediação do conhecimento geográfico.

O capítulo 12 é, essencialmente, uma reflexão sobre o livro como um todo, levando-nos de volta para a presente discussão sobre as expectativas da geografia na educação. O capítulo final sugere que as características de um ensino de geografia devem ter, antes de tudo, preocupações de natureza ética. 